\title{
Adaptation of the Word Subtest of the Reading Decision Test (RDT) for Brazilian Portuguese
}

\author{
Adaptação do Subteste de Leitura do Reading Decision Test (RDT) \\ para o Português Brasileiro
}

\author{
Elayne Cristina Morais Pinheiro ${ }^{*}, a$, Thaís Barbosa ${ }^{a}$, Mônica Carolina Miranda ${ }^{b}$, \\ Alan Baddeley ${ }^{c}$, Ana Luiza Gomes Pinto Navas ${ }^{d} \&$ Orlando Francisco Amodeo Bueno ${ }^{a}$ \\ ${ }^{a}$ Universidade Federal de São Paulo, São Paulo, SP, Brasil, \\ ${ }^{b}$ Associação Fundo de Incentivo à Pesquisa, São Paulo, SP, Brasil, \\ ${ }^{c}$ University of York, York, North Yorkshire, England \\ \& ${ }^{d}$ Faculdade de Ciências Médicas da Santa Casa de São Paulo, São Paulo, SP, Brasil
}

\begin{abstract}
Screening tests for reading skills are essential instruments for teachers and professionals in educational settings. This study examines an adaptation of the lexical decision subtest of the Reading Decision Test (RDT), which has two equally weighted forms, each containing words and pseudo-words, to Brazilian Portuguese. The adaptation followed standards recommended by the international literature and was applied to a sample of 230 schoolchildren from $1^{\text {st }}$ to $5^{\text {th }}$ grades in order to analyze its initial psychometric properties. Item analysis and reading speed showed significant school-year effect ( $p$ $<.05)$. Scores on the two forms of the subtest were closely correlated. In conclusion, the RDT word decision subtest showed appropriate initial psychometric properties.

Keywords: Reading disability, reading test, adaptation.
\end{abstract}

\begin{abstract}
Resumo
Testes rápidos (screenings) de avaliação de leitura são instrumentos essenciais para professores e profissionais no âmbito educacional. Este estudo adaptou para o português o subteste de leitura de palavras do Reading Decision Test (RDT), o qual tem duas formas equivalentes, compostas por palavras e pseudopalavras. O processo de adaptação seguiu as regras recomendadas pela literatura internacional e foi aplicado em uma amostra de 230 escolares, do $1^{\circ}$ ao $5^{\circ}$ ano do ensino fundamental para analisar as propriedades psicométricas iniciais. Observou-se que as análises de itens e da velocidade de leitura mostraram efeito significativo do ano escolar $(p<0,05)$. Verificou-se também forte correlação entre as duas formas do subteste. Conclui-se que o subteste de palavras do RDT apresenta propriedades psicométricas iniciais adequadas.
\end{abstract}

Palavras-chave: Dificuldade de desenvolvimento de leitura, teste de leitura, adaptação.

Reading is characterized as a psycholinguistic activity comprised of multiple interdependent processes, in which word recognition (retrieval from lexicon) and comprehension of contents are crucial (Alégria, Leybaert, \& Mousty, 1997; Salles, Jou, \& Stein, 2007). An adequate reading test must be capable of assessing both word decoding and comprehension. However, for regular orthographies, developing such a tool is an arduous task because the word decoding process may not be associated with comprehension (Alcock et al., 2000). In regular orthographies,

\footnotetext{
" Mailing address: Departamento de Psicobiologia, Universidade Federal de São Paulo, Rua Botucatu, 862, $1^{\circ}$ andar, Edifício de Ciências Biomédicas, São Paulo, SP, Brasil 04023-062. E-mail: elaynemorais@yahoo.com. br, barbosa thais@hotmail.com, mirandambr@hotmail. com, a.baddeley@york.ac.uk, analunavas@gmail.com and ofabueno@gmail.com
}

the pronunciation of each word clearly and unambiguously reflects its spelling (Ellis, 1995) by transposing each grapheme (consisting of one or two letters) to a phoneme (speech sound) using rules of correspondence (Nilsen \& Bourassa, 2008). Therefore, it is possible to read a word correctly without the activation of the word's meaning using a phonological-orthographic strategy, which may be used for reading of pseudowords. Compared with English, Brazilian Portuguese may be characterized as regular, or almost regular, since there are only a few irregularities (Parente, Silveira, \& Lecours, 1997).

The most widely accepted cognitive processing model for reading is the dual-route model (Pinheiro \& RotheNeves, 2001), which suggests that word pronunciation takes two interactive routes: phonological and lexical (Coltheart, Curts, Atkins, \& Haller, 1993; Coltheart, Rastle, Perry, Langdon, \& Ziegler, 2001; Ellis, 1995; Ellis 
\& Young, 1988). The phonological route uses graphemephoneme conversion rules and the meaning of a word is accessed indirectly through its pronunciation, identified by the phonemic lexical system, whereas the lexical route depends on prior knowledge of a word and its storage in the visual orthographic lexicon, with pronunciation and meaning accessed together.

When reading a word, the use of the lexical or phonological route will vary according to the type of stimuli presented. This will be determined by the psycholinguistic characteristics of the word (Capovilla, Macedo, \& Charin, 2002), which is related to its regularity, lexicality, frequency and length.

Regularity refers to the type of letter-sound correspondence. Words are classified into three categories: (a) regular, in which letters always represent the same sound (e.g. pato); (b) regular and by rule, for words that have letter-sound matches governed by rules (e.g. graphemes $<\mathrm{r}>$ and $<\mathrm{s}>$ intervocalic, which represent respectively, the phonemes /I/ $<$ girafa $>$ and $/ \mathrm{z} /<$ rosa $>$ ); (c) irregular, which refers to ambiguous matches, where a letter may be associated with more than one sound in a non-rulegoverned manner (Pinheiro, 1999).

In the process of reading Brazilian Portuguese, there are only three letters that show ambiguity in relation to their sounds, $\mathbf{x}, \mathbf{e}$ and $\mathbf{o}$ (Parente et al., 1997). The grapheme $<x>$ in any position in a word may be associated with four different phonemes: /f/ (e.g. xícara), /s/ (e.g. máximo), $/ \mathrm{ks} /$ (e.g. boxe), or $/ \mathrm{z} /$ (e.g. exato). The vowels $<\mathrm{e}>$ and $<0>$ are also ambiguous in relation to their sounds. In the paroxytone position, they may become open vowels $/ \varepsilon /$ or $/ \square /$, as in $\langle$ canela $\rangle$ or $\langle$ bigode $>$, or closed vowels /e/ or /o/, as in $\langle$ cabelo $\rangle$ or $\langle$ estojo $\rangle$. Reading these words through the phonological route tends to regularize them, leading to incorrect pronunciation compared with that produced by the lexical route (e.g. boxe is read as "boche" instead of /b ksi/; Salles \& Parente, 2007).

Lexicality refers to the nature of the stimulus, which may be a word or a pseudoword (a pronounceable sequence of letters that has no meaning; Pinheiro \& Rothe-Neves, 2001). Pseudowords are read through the phonological route alone, since they are not found in the lexicon (e.g. zapa).

The relative number of occurrences of a word in a language is referred to as its frequency. Since readers are constantly in contact with high-frequency words, their mental lexicon is rapidly activated (Lúcio, 2008). The preference is for reading them through the lexical route, whereas less frequent words that cannot be recognized are usually read through the phonological route (Pinheiro \& Rothe-Neves, 2001).

Finally, word length refers to the number of letters composing a stimulus. The longer the word, the more likely reading will be slow and error prone (Salles \& Parente, 2007). In terms of memory load, shorter words are read more accurately through the phonological route than longer ones.
These varied and contrasting psycholinguistic characteristics are indicators of the underlying process of reading any given word. In general, high frequency words, whether long or short, regular or irregular, may be read correctly through the lexical route, whereas processing pseudowords and low-frequency, regular short words are preferred to be read through the phonological route.

Reading aloud tasks, which have been shown to be efficient ways of testing the reading processes (lexical or phonological), consist of showing lists of words and pseudowords, which must be read aloud as quickly and accurately as possible (Pinheiro \& Rothe-Neves, 2001). The distinct psycholinguistic characteristics of list items produce reading effects (regularity, lexicality, e.g.) that have been observed in several studies of English speakers in developed countries (Katz et al., 2012; Rastle \& Coltheart, 1999; Seidenberg, Waters, Barnes, \& Tanenhaus, 1984 ) and for other languages as Portuguese (Cunha \& Capellini, 2009, 2010; Salles \& Parente, 2007; Salles, Parente, \& Freitas, 2010), showing that the contributions made by phonological and lexical processes may differ with the characteristics of orthography in each language. Differing grapheme-phoneme relationships appear to prompt differing speeds of lexical and phonological processing across different languages (Ziegler, Perry, \& Coltheart, 2003).

A study conducted in Tanzania (Alcock et al., 2000), where they have a regular orthography, used a direct translation of the WRAT (Jastak \& Jastak, 1965) readaloud instrument for schoolchildren in grades 1-4. The results showed discrepancies (ceiling or floor effect), and the instrument was not adequate to discriminate between participants at different reading levels. This goes to show that the direct translation of instruments is not appropriate because orthography and particular characteristics of the language are not followed, and consequently, the test is not sensitive and does not adequately differentiate the groups. In addition, untimed reading aloud may not be the most suitable task when testing reading skills of subjects in a regular orthography. That is because orthography in these languages facilitates word decoding, and subjects may obtain high scores in reading aloud, but there is no guarantee that they understand the contents.

Based on these results, the same group in Tanzania developed a new test with gradually increasing levels of difficulty that enabled them to evaluate text decoding and comprehension processes with three subtests: (a) a letter subtest that assessed children's ability to recognize written letters by asking them to decide which are real and which are not; (b) a word subtest that measured ability to discriminate pseudowords from words that have known meanings, and (c) a sentence subtest that evaluated speed of reading comprehension, as the child has to distinguish sentences with real meanings from nonsense sentences.

The test was developed on the basis of lexical decision tasks, which are widely used to examine how subjects identify words (Lupker \& Pexman, 2010). Each subtest has two equivalent versions, so each child may be evaluated 
Pinheiro, E. C. M., Barbosa, T., Miranda, M. C., Baddeley, A., Navas, A. L. G. P. \& Bueno, O. F. A. (2015). Adaptation of the Word Subtest of the Reading Decision Test (RDT) for Brazilian Portuguese.

at two different times (Alcock et al., 2000). The Tanzania study tested children of both genders aged 9-14. A reliability analysis for the three sub-tests was conducted a week later, and the retesting showed an adequate coefficient of correlation.

In 2003 , the letter and word reading subtests were adapted and validated for the United Kingdom to compile the Reading Decision Test (RDT; Baddeley, Gathercole, \& Spooner, 2003), which was standardized for children aged 4-11, and has been used in later studies (Bayliss, Jarrold, Baddeley, \& Leigh, 2005; Burgoyne, Whiteley, \& Hutchinson, 2013; Engel de Abreu, Gathercole, \& Martin, 2011). Its measures involve determining reading age (estimated in years and months). A reliability check was also conducted, as in the Tanzanian study, and validated by correlating with isolated word tests from the British Ability Scales and SAT reading scores. These results obtained correlation coefficients of .97 and .77, respectively. Studies carried out in Tanzania and the UK showed that the RDT has adequate psychometric qualities.

Since this test was developed to be administered collectively, large samples may be tested and it is an efficacious means of identifying reading acquisition delays, thus enabling appropriate referral for full assessment and early diagnosis of specific reading difficulty or disorders (dyslexia). The RDT can thus assist with early detection of adverse effects and intervention to improve child development.

Research with read-aloud tasks conducted in Brazil (Godoy, 2008; Pinheiro, 1994; Salles \& Parente, 2007) showed that children in the early stages reading make parallel use of both phonological and lexical routes, but phonological processes predominate. However, there were no normative data for the lists used in these studies.

The Brazilian "School Performance Test" (Teste de Desempenho Escolar - TDE; Stein, 1994) contains a word-reading subtest that has been normatized for Brazilian subjects. On the other hand, the TDE has certain limitations, since the number of items described as "easy" (highly regular items) is greater than the small quantity of items with higher levels of difficulty (irregular words). Moreover, the normative data for the TDE did not show significant differences between school years, which limits its ability to discriminate the different reading skills in different school years (Lúcio, Pinheiro, \& Nascimento, 2009).

Brazil lacks a screening instrument adapted for educators or health professionals to administer collectively in order to test acquisition of basic reading skills quickly, effectively and inexpensively. Therefore, the RDT was adapted to Brazilian Portuguese and the present study aims to show the adaptation of the word subtest.

\section{Method}

The RDT adaptation process used criteria recommended by the international literature (Giusti \& Befi-Lopes, 2008) and comprised the following phases:

\section{Phase 1 - Adapting the RDT Word Subtest}

The word subtest adaptation was based on criteria established for the versions used in Tanzania (Alcock et al., 2000) and the UK (Baddeley et al., 2003) while recognizing the psycholinguistic aspects of Brazilian Portuguese. The present study's adaptation covered the two subtest forms (1 and 2).

Each form consists of 40 stimuli (20 real words and 20 pseudowords), which are different for each form. Items were randomly distributed on two sheets of A4 paper, each containing two columns with 10 items printed in the same Century Gothic type font used for the UK version.

The test comprised words selected from a study by Pinheiro (1996). Only the word list of high and low frequency words for each school-year (from preschool to $4^{\text {th }}$ year) were used, building up to a total of 10 lists.

It is noteworthy that in one school year some words were characterized as low frequency, but the same words were later classified as high frequency for the following year. For this reason, the lists of low frequency words from each school year were compared to the list of high frequency words from the subsequent school-year. However, this comparison was not carried out for the $3^{\text {rd }}$ and $4^{\text {th }}$ school year, because both lists were similar and the authors compared the both lists within the same school year, rather than comparing the low frequency list from one year with the high frequency list from the other. Additionally, as there was no high frequency list prior to the preschool year, this list was compared to the high frequency list from the $1^{\text {st }}$ school year.

These comparisons served to discriminate the words appearing concomitantly in both lists, and these words were discarded. After such comparisons, other criteria were established for the choice of the words: (a) words classified as concrete nouns (e.g. prato, raquete); (b) two or three syllable words (e.g. motor, bochecha); (c) regular or irregular words (e.g. sanfona, roxo).

Regarding the comparisons between the lists, it was observed that a small number of words were characterized as concrete nouns and belonging to both lists. The majority of words maintained their classification despite the fact that their occurrence increased in the following years. Therefore, the words with these characteristics were compared with those from the lists of same frequency in subsequent years. The low frequency words were not present in the lists from previous school years, but they appeared with higher frequencies in subsequent years. Thus, in order to be part of the $2^{\text {nd }}$ year list, the word could not appear on the lists from either preschool or $1^{\text {st }}$ year, however, they could have appeared on the lists from the $3^{\text {rd }}$ and $4^{\text {th }}$ years. In that case, when a particular word appears for the first time in the low frequency list from the $2^{\text {nd }}$ year, it is highly likely that this word is exposed to children from this school year, and it may represent this school year. On the other hand, the high frequency words were chosen when they presented the highest frequency in the lists from each school year, whether or not they had already appeared in other lists. As a 
result, all words in conformation with the above mentioned criteria were compiled for Phase 2 of the study.

\section{Phase 2 - Analysis of Items by Expert Judges}

Since each form consists of 20 words, the final selection needs 40 items. In relation to the word-length criterion, both short and long words were selected for years 1 to 3, but long words only for years 4 and 5. Both regular and irregular words were selected for years 1 and 2, while irregular items predominated for year 3 and onwards (Figure 1). Initially 40 words were selected for each subtest form, making a total of 80 words. Two words with the same characteristics were selected for each form, from which the expert judges would choose one. The criteria for this selection were distributed by school year as shown in Figure 1.

\begin{tabular}{|c|c|c|c|}
\hline \multicolumn{2}{|c|}{ Low-frequency words } & \multicolumn{2}{|c|}{ High-frequency words } \\
\hline \multicolumn{4}{|c|}{ YEAR 1} \\
\hline $\begin{array}{l}1 \text { regular short word } \\
(4-5 \text { letters })\end{array}$ & $\begin{array}{l}1 \text { irregular short word } \\
\quad(4-5 \text { letters })\end{array}$ & $\begin{array}{l}1 \text { regular short word } \\
(4-5 \text { letters })\end{array}$ & $\begin{array}{l}1 \text { regular long word } \\
(6-8 \text { letters })\end{array}$ \\
\hline \multicolumn{4}{|c|}{ YEAR 2} \\
\hline $\begin{array}{l}1 \text { regular short word } \\
(4-5 \text { letters })\end{array}$ & $\begin{array}{l}1 \text { irregular long word } \\
\text { (6-8 letters) }\end{array}$ & $\begin{array}{l}1 \text { regular short word } \\
\text { (4-5 letters) }\end{array}$ & $\begin{array}{l}1 \text { regular long word } \\
\text { (6-8 letters) }\end{array}$ \\
\hline \multicolumn{4}{|c|}{ YEAR 3} \\
\hline $\begin{array}{l}1 \text { irregular long word } \\
\quad(6-8 \text { letters })\end{array}$ & $\begin{array}{l}1 \text { irregular long word - rule } \\
\text { governed (6-8 letters) }\end{array}$ & $\begin{array}{l}1 \text { regular long word } \\
\text { (6-8 letters) }\end{array}$ & $\begin{array}{l}1 \text { irregular long word } \\
\quad(6-8 \text { letters })\end{array}$ \\
\hline \multicolumn{4}{|c|}{ YEAR 4} \\
\hline $\begin{array}{c}2 \text { irregular long wo } \\
(6-8 \text { letters })\end{array}$ & $\begin{array}{r}1 \text { irregular long } \\
(6-8\end{array}$ & $\begin{array}{l}\text { d rule governed } \\
\text { ers) }\end{array}$ & $\begin{array}{c}1 \text { regular long word } \\
(6-8 \text { letters })\end{array}$ \\
\hline \multicolumn{4}{|c|}{ YEAR 5} \\
\hline $\begin{array}{c}2 \text { irregular long wo } \\
\text { (6-8 letters) }\end{array}$ & $\begin{array}{r}1 \text { irregular long } \mathrm{w} \\
(6-8\end{array}$ & $\begin{array}{l}\text { - rule governed } \\
\text { ers) }\end{array}$ & $\begin{array}{l}1 \text { long irregular word } \\
\text { (6-8 letters) }\end{array}$ \\
\hline
\end{tabular}

Figure 1. Distribution of criteria for selecting words $(n=20)$ for each word decision subtest form, based on frequency in Portuguese language and school year.

The judging committee consisted of two experts with experience in testing learning disorders, one of them a neuropsychologist and the other a speech-language therapist. Each expert was given general information about the subtest that explained the origin of the task, its purpose and the manner in which it would be administered. The word list shown to the experts was similar to Figure 1 and they were asked to judge items by marking " $X$ " against the word that best fit the characteristics shown for each school year.

After judges rated the items, their choices were compared and in cases where there was agreement between them, the word was selected for inclusion in the subtest. If there was no agreement, one of the words selected by the judges was randomly chosen for the subtest by holding a draw.

Pseudowords were not selected by the experts. Some were chosen from word frequency lists developed by studies conducted in Brazil (Cruz, 2004; Pinheiro, 1994; Salles, 2005). Others were produced by switching two or more graphemes, or reversing the positions of letters in words selected by the experts, as suggested by the authors of the
RDT 's UK version (Baddeley et al., 2003). The adequacy of these items was examined by analyzing the frequency of errors in the pilot study. At the end of this stage, two equivalent forms of the RDT word subtest were obtained in Brazilian Portuguese.

\section{Phase 3 - Pilot Study}

Participants. A pilot study was conducted to analyze the adequacy of the adaptation process with 40 participants of both sexes, 6 to 10 years old, from public schools in São Paulo. Twenty of these children had a record of belowaverage school performance, and 20 good performance as assessed by their teachers. Inclusion criteria for this study were children having no history of failing a school year (thus no discrepancy between age and school year); no signs of neurological or psychiatric alterations, or uncorrected sensory deficits (auditory or visual); showing the psychomotor development and intelligence level expected for their age. For this purpose, the following instruments were used: reading pseudowords (Pinheiro, 1994); Raven's Coloured Progressive Matrices Test (Angelini, Alves, 
Pinheiro, E. C. M., Barbosa, T., Miranda, M. C., Baddeley, A., Navas, A. L. G. P. \& Bueno, O. F. A. (2015). Adaptation of the Word Subtest of the Reading Decision Test (RDT) for Brazilian Portuguese.

Custódio, Duarte, \& Duarte, 1999); and the reading subtest from the Brazilian School Performance Test (TDE; Stein, 1994).

Shapiro-Wilk test was used to verify if the scores of right answers had a normal distribution, considering the school-year. In order to compare the groups with and without learning difficulty, the $t$-Student test was used for normally distributed data, and the Mann-Whitney test, for the non-normally distributed data. Item adequacy was analyzed based on level of difficulty $(p)$, as rated by the proportion of subjects responding correctly for each item (Conde \& Laros, 2007) Statistical Package for the Social Sciences (SPSS), version 18.0 for Windows was used and the significance level adopted was $p<.05$.

Results from the Pilot Study. Considering the results from the Form 1 word subtest, from children in the $3^{\text {rd }}$, $4^{\text {th }}$ and $5^{\text {th }}$ years, the performance of participants with and without difficulties were significantly different in the $3^{\text {rd }}$ $(p=.002)$ and $5^{\text {th }}(p=.018)$ school-years. When analysing Form 2, both groups (with and without learning difficulties) were significantly different in all three school years $\left(3^{\text {rd }}, 4^{\text {th }}\right.$ and $\left.5^{\text {th }} ; p<.012\right)$. The comparisons between the groups from the $1^{\text {st }}$ and $2^{\text {nd }}$ school years were not carried out because none of the children from the group with learning difficulty was able to answer the test.

Regarding the test execution time, it was observed that the group without learning difficulty answered Forms 1 and 2 of the subtest in a median time varying from 2 $\min 45 \mathrm{~s}$ to $2 \mathrm{~min} 25 \mathrm{~s}$, for participants from the $3^{\text {rd }}$ to $5^{\text {th }}$ year, respectively. Therefore, differently to the $4 \mathrm{~min}$ interruption criteria determined on the English version of the word subtest, the time of 3 min was chosen for this version of the test.

\section{Phase 4 - Analysis of the Psychometric Properties}

Participants. A total of 230 students, aged 6 to 10 years, were selected from years 1 to 5 from three elementary schools in the city of São Paulo, which are part of the State of São Paulo's public school system. A sample of 46 students was randomly selected from each school year, half from each gender. Twenty-five children were excluded from the study since their parents did not consent on their participation. Eleven additional children did not complete one or both test forms. These children were substituted in the study sample so that we could get the number of subjects reported before.

Procedures. The two subtest forms were administered randomly in two collective sessions held at the school with a one-week interval. Participants were divided into groups of up to twelve members, all from the same school year. In the first session, half of the group took form 1 of the subtest, while the other part took form 2. At the next session, those who had taken form 1 took form 2 and vice versa, so that each child took both versions of the subtest.

Testing followed the same procedure as the original instrument, described below. On administering the subtest, children were told that they would see several words. Some of them would be real Portuguese words with meanings while others would have no meaning. Using the stimuli in the practice space on the cover of the subtest, participants were told to mark words they knew to be real words with a tick $(\checkmark)$, and mark those they thought were "made-up" words with an " $X$ ". The aim of this procedure was to ensure participants had understood instructions, which were repeated to clear up any issues if required. After checking that everybody had responded correctly in the practice space, participants were then asked to wait for permission to start the subtest.

Test completion time was once again measured. For that, a chronometer was used and the children were instructed to raise their hand as soon as they had concluded the task. The time taken for each child to complete the test was written on the test itself. However, after 3 minutes (task completion time determined by the pilot study) participants were instructed to underline the item corresponding to their most recent response. Then they were told to go on to complete the task if they had not finished it in the stipulated time. The duration of the total subtest completion was individually registered by the tester.

For scoring purposes, one point was assigned to each correctly responded item, the maximum being 40 points. All subtests were scored by one single tester. The number of items each child was able to answer within 3 minutes, and the number of items answered correctly after that time were noted.

\section{Statistical Analysis}

The Shapiro-Wilk test was used to analyze scores of right answers and time for normal distribution. Since the results did not show normal distribution, the KruskalWallis test was used followed by Mann-Whitney to locate differences between years of schooling and completion time for the subtest versions. The Wilcoxon test was used to investigate differences between the two subtest forms. Item-total (I-T) correlation was also analyzed to verify the word subtest's homogeneity. Cronbach alpha values were calculated for words on both forms. Intra-class and Spearman correlation tests were used to compare scores on the two forms of the test. The significance level adopted for all analyses was $p<.05$, and the SPSS version 18.0 statistical package for Windows was used.

\section{Results}

Table 1 presented the mean and standard deviation of words and pseudowords considering school year. There were no significant school-year effects for words or pseudowords on either subtest form. Year 1 participants' word reading scores were lower than all other school years on both subtest forms $(p<.05)$. Year 2 and 3 participants' scores were statistically similar but lower than those of years 4 and 5, whose scores were similar to each other.

In relation to pseudowords, in general, it was noted that on both forms, only year 1 children's mean scores 
were significantly lower than those of the other school years.

Table 2 shows the average number of correct responses for words and pseudowords, inter- and intra-version. There were statistically significant differ- ences for all school years, for both forms of the subtest. However, when comparing each individual type of item (word or pseudoword) between the two forms of the subtest, there was no statistical difference for any of the school years.

Table 1

Mean and Standard Deviation (SD) of Correct Responses to Both Types of Stimuli (words and pseudowords) on the Word Subtest, by School Year

\begin{tabular}{|c|c|c|c|c|c|c|c|c|}
\hline \multirow{3}{*}{ School Year } & \multicolumn{4}{|c|}{ FORM 1} & \multicolumn{4}{|c|}{ FORM 2} \\
\hline & \multicolumn{2}{|c|}{ Words } & \multicolumn{2}{|c|}{ Pseudowords } & \multicolumn{2}{|c|}{ Words } & \multicolumn{2}{|c|}{ Pseudowords } \\
\hline & Mean & $S D$ & Mean & $S D$ & Mean & $S D$ & Mean & $S D$ \\
\hline 1 & $9.7^{\mathrm{a}}$ & \pm 5.3 & $14.3^{\mathrm{a}}$ & \pm 5.5 & $9.5^{\mathrm{a}}$ & \pm 5.3 & $14.8^{\mathrm{a}}$ & \pm 5.6 \\
\hline 2 & $13.5^{\mathrm{b}}$ & \pm 3.0 & $18.2^{\mathrm{b}}$ & \pm 3.1 & $13.8^{\mathrm{b}}$ & \pm 3.3 & $17.9^{\mathrm{b}}$ & \pm 2.9 \\
\hline 3 & $14.5^{\mathrm{b}}$ & \pm 3.0 & $18.1^{\mathrm{b}}$ & \pm 3.1 & $14.9^{\mathrm{b}}$ & \pm 2.7 & $18.2^{\mathrm{b}}$ & \pm 2.9 \\
\hline 4 & $17.3^{c}$ & \pm 1.4 & $19.3^{\mathrm{b}}$ & \pm .9 & $18.9^{\mathrm{c}}$ & \pm 1.5 & $18.9^{b}$ & \pm 1.5 \\
\hline 5 & $17.00^{\mathrm{c}}$ & \pm 1.8 & $19.2^{\mathrm{b}}$ & \pm 1.3 & $19.4^{c}$ & \pm .9 & $19.4^{\mathrm{c}}$ & \pm .9 \\
\hline
\end{tabular}

Note. Different letters $\left({ }^{\mathrm{abc}}\right)$ : significant differences between groups on the Mann-Whitney test $\left(p_{\mathrm{S}}<.05\right.$ with Bonferroni correction).

Table 2

Significance (p-values) of Comparisons between Words and Pseudowords, Inter-and Intra-Version (forms 1 and 2)

\begin{tabular}{lccccc}
\hline \multicolumn{1}{c}{ Comparisons } & \multicolumn{5}{c}{ School Year } \\
\cline { 2 - 6 } & \multicolumn{1}{c}{1} & 2 & 3 & 4 & 5 \\
\cline { 2 - 6 } Words F1 X Pseudowords F1 & $.002^{*}$ & $<.001^{*}$ & $<.001^{*}$ & $<.001^{*}$ & $<.001^{*}$ \\
Words F2 X Pseudowords F2 & $<.001^{*}$ & $<.001^{*}$ & $<.001^{*}$ & $<.001^{*}$ & $<.001^{*}$ \\
Words F1 X Words F2 & .855 & .401 & .446 & .116 & .059 \\
Pseudowords F1 X Pseudowords F2 & .298 & .228 & .778 & .140 & .521 \\
\hline
\end{tabular}

Note. Wilcoxon test: * significant differences across comparisons for the same school year $(p<.05)$. V1 and V2: Forms 1 and 2 of the word subtest, respectively.

In relation to the analyses of number of correct responses in 3 minutes and in total completion time (Table 3), Year 1 participants scored significantly lower on both subtest forms than other school years after 3 minutes. Results of year 2 and 3 participants were different to each other, showing year 3 students had a better performance than year 2. There was no statistical difference between year 4 and 5 children, whose results were statistically higher than those of other school years.

Statistical analysis showed that the older the school year, the shorter the time taken to complete the subtest. Year 1 participants took significantly longer to complete the task than the others; years 2 and 3 did not differ between themselves, but took longer than year 4 or 5 ; year 4 and 5 participants did not differ between themselves (Table 3).
Figure 1 shows the distribution of words for each subtest version by level of difficulty $(p)$ (proportion of correct responses) for children. Few words showed a high, or average, level of difficulty $(.20 \leq p<.40$ or $.40 \leq p<.60$, respectively). Most words were rated as easy $(.60 \leq p<.85)$ or very easy $(.85 \leq p<.90)$. Only the word ampola on subtest form 2 , showed a very high level of difficulty $(p<.20)$.

To verify subtest homogeneity, item-total (I-T) correlation was analyzed and showed adequate levels (I-T $\geq$ .30) for most words on both forms, thus confirming their homogeneity. Only three words in each form showed lower item-total correlation than estimated: In form 1- maxixe, enxofre and galáxia; In form 2-carpete, ampola and maxilar. Cronbach's alpha values calculated for words in both forms were the same and considered to have reached a satisfactory level (Cronbach's alpha for forms 1 and $2=.85$ ). 
Pinheiro, E. C. M., Barbosa, T., Miranda, M. C., Baddeley, A., Navas, A. L. G. P. \& Bueno, O. F. A. (2015). Adaptation of the Word Subtest of the Reading Decision Test (RDT) for Brazilian Portuguese.

Finally, in relation to the investigation of possible differences between versions, the intra-class correlation analysis $(r=.90: p<.001)$ and Spearman correlation test $(r=.83 ; p<.001)$ showed a strong relationship between scores on both subtest versions.

Table 3

Mean and Standard Deviation (SD) Number of Correct Responses in 3 Minutes and in Total Completion Time for Participants on Each Form of the Word Subtest by School Year

\begin{tabular}{|c|c|c|c|c|}
\hline \multirow{3}{*}{ School Year } & \multicolumn{2}{|c|}{ FORM1 } & \multicolumn{2}{|c|}{ FORM2 } \\
\hline & Hits & Time & Hits & Time \\
\hline & Mean $(S D)$ & Mean $(S D)$ & Mean $(S D)$ & Mean $(S D)$ \\
\hline 1 & $14.7( \pm 8.0)^{\mathrm{a}}$ & $5^{\prime} 11^{\prime \prime}\left( \pm 2^{\prime} 30^{\prime \prime}\right)^{\mathrm{a}}$ & $16.2( \pm 8.3)^{\mathrm{a}}$ & $4^{\prime} 57^{\prime \prime}\left( \pm 2^{\prime} 58^{\prime \prime}\right)^{a}$ \\
\hline 2 & $26.6( \pm 8.3)^{\mathrm{b}}$ & $3^{\prime} 37^{\prime \prime}\left( \pm 1^{\prime} 33^{\prime \prime}\right)^{\mathrm{b}}$ & $26.3( \pm 9.4)^{\mathrm{b}}$ & $3{ }^{\prime} 45^{\prime \prime}\left( \pm 1^{\prime} 30^{\prime \prime}\right)^{b}$ \\
\hline 3 & $29.8( \pm 8.7)^{\mathrm{c}}$ & $3^{\prime} 11^{\prime \prime}\left( \pm 1^{\prime} 51^{\prime \prime}\right)^{\mathrm{b}}$ & $29.6( \pm 9.2)^{\mathrm{c}}$ & $3^{\prime} 17^{\prime \prime}\left( \pm 1^{\prime} 42^{\prime \prime}\right)^{b}$ \\
\hline 4 & $35.4( \pm 4.8)^{\mathrm{d}}$ & $2{ }^{\prime} 17^{\prime \prime}\left( \pm 0,48^{\prime \prime}\right)^{\mathrm{c}}$ & $35.2( \pm 3.3)^{\mathrm{d}}$ & $2^{\prime} 06^{\prime \prime}\left( \pm 0^{\prime} 43^{\prime \prime}\right)^{c}$ \\
\hline 5 & $35.4( \pm 3.9)^{\mathrm{d}}$ & $2{ }^{\prime} 14^{\prime \prime}\left( \pm 0^{\prime} 47^{\prime \prime}\right)^{\mathrm{c}}$ & $36.0( \pm 2.4)^{\mathrm{d}}$ & $1^{\prime} 56^{\prime \prime}\left( \pm 0^{\prime} 35^{\prime \prime}\right)^{\mathrm{c}}$ \\
\hline
\end{tabular}

Note. Different letters $\left({ }^{a b c}\right)$ : significant differences between groups on the Mann-Whitney test $(p s<.05$ with Bonferroni correction).

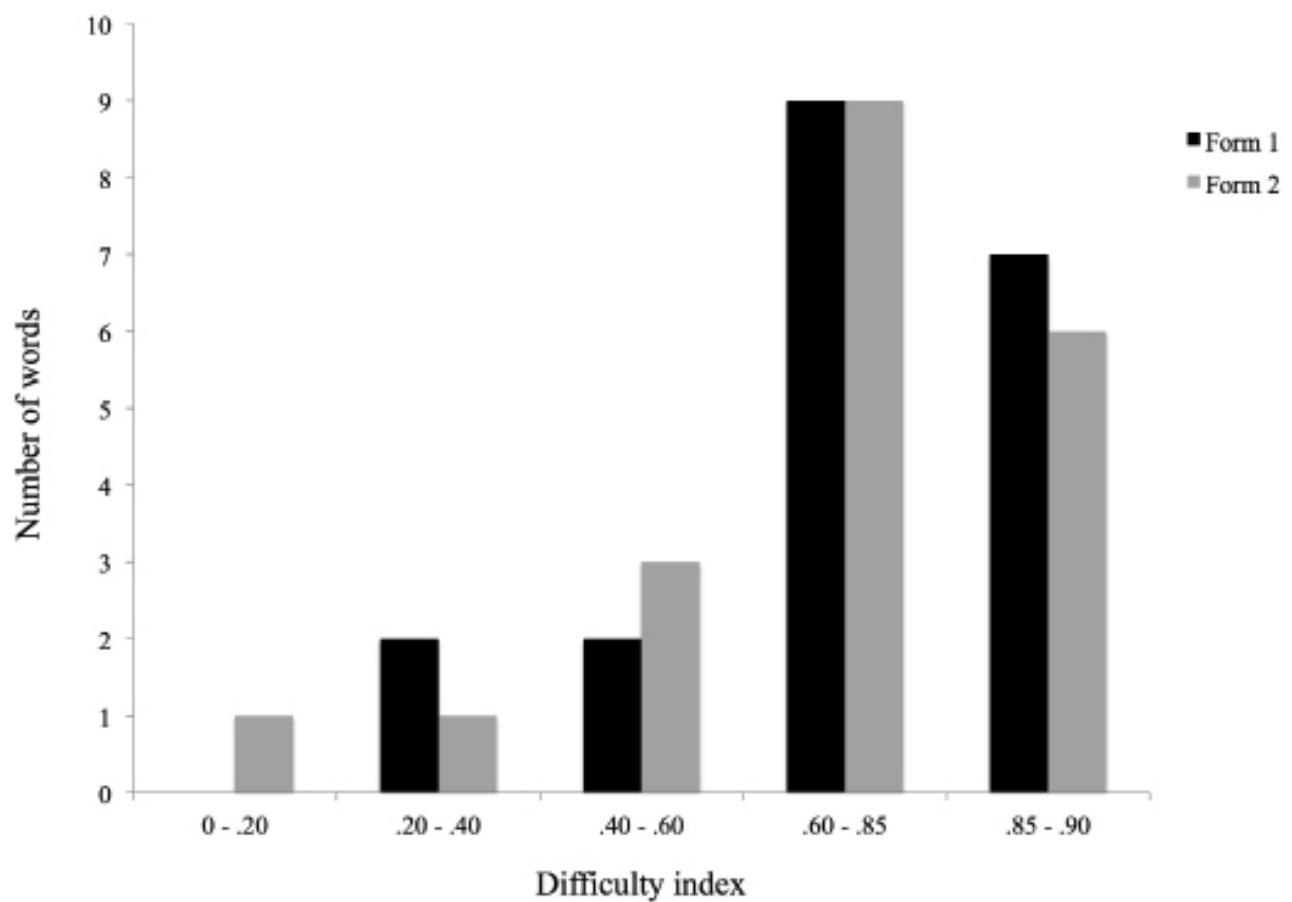

Figure 2. Distribution of words on both subtests forms by level of difficulty [very high $(p<.20)$, high $(.20 \leq p<.40)$, average (.40 $\leq p<.60)$, easy $(.60 \leq p<.85)$, very easy $(.85 \leq p<.90)]$.

\section{Discussion}

The present study described the adaptation of the word subtest of the Reading Decision Test (RDT) for Brazilian Portuguese and analyzed its initial psychometric properties. The results showed that both subtest forms have a school-year effect on the discrimination between words and pseudowords, and on processing speed for reading that started when children began to learn reading and writing (year 1 children), with an increasing number of items correctly identified by older year groups. Words used to compile both versions were shown to be adequate, showing 
the task was homogeneous, and there were no differences between items on both forms of the subtest.

In this word subtest, based on the lexical decision paradigm, subjects do not perform well unless there is access to the mental lexicon (Alcock et al., 2000; Lupker \& Pexman, 2010). Therefore, to identify a given word correctly, the subject must have come into contact with this stimulus (Nilsen \& Bourassa, 2008) previously. Furthermore, the higher scores for correctly discriminated words obtained by the older school years seem to be related to their greater lexicon knowledge. A larger lexical repertoire, acquired by exposure to different types of stimuli over the years leads to adequate reading of words classified as irregular and / or low frequency (Salles \& Parente, 2002). Also, in Brazilian Portuguese the phonological aspects of the regular orthography might help readers to achieve success in reading, since the automaticity of the decoding process is mastered earlier in development. The present results showed similar school-year effects as findings for two earlier versions of the RDT (Alcock et al., 2000; Baddeley et al., 2003).

The analysis of the words used to compile the two subtest versions showed that words classified as easy or very easy were mostly high or low frequency regular words. Those that showed higher levels of difficulty were predominantly low-frequency irregular words. This indicates that regularity is the psycholinguistic characteristic that contributes most to the differences observed between the groups, thus confirming the theoretical assumption that the use of irregular words for reading leads to their regularization and affects numbers of errors (Pinheiro \& Rothe-Neves, 2001). This result also corroborates findings from other studies (Lúcio, 2008; Pinheiro, 1994; Salles \& Parente, 2007) that showed irregular items are more discriminating than regular ones in reading tests. Although the analysis of level of difficulty of words has shown a low level of difficulty, the irregular character of some words was responsible for the school year effect.

Furthermore, the presence of irregular words among the most difficult ones shows that the level of difficulty of a word presented to a beginner reader is related to the reading process used. In the early years of learning, there is a predominance of phonological processing (Godoy, 2008; Pinheiro, 1994; Salles \& Parente, 2007) the application of grapheme-phoneme transposition rules produces an incorrect phonological representation of the irregular word, and when the child compares this stimulus with material stored in the lexicon, it is not recognized as a real word.

It is important to note that irregular words tend to be taught to children later and require more exposure than regular words to be read correctly (Salles, 2005). The predominant use of the phonological route in the initial process of learning to read and write enables adequate discrimination of pseudowords. On the other hand, application of appropriate grapheme-phoneme conversion rules for this process prompts decoding errors for irregular words, generating an incorrect phonological representation, thus preventing identification as words.

For both test forms there was three words with lower item-total correlations. All three words have similar psycholinguistics characteristics, e.g. long, irregular and low frequency words. Taken together, these characteristics may increase the chance of a child to make a mistake, for instance, lexicalization or regularization of a word.

In relation to the influence of time (speed of reading process) on the subtest score, it was observed that the predetermined time of 3 min showed the school-year effect. The total time of execution confirmed that there are significant differences regarding the reading process. The fact that children from the $2^{\text {nd }}$ and $3^{\text {rd }}$ school-year had similar reading speed suggests that there is a learning consolidation process of the grapheme-phoneme conversion rules, which, in turn, are applied in a more rapid rate. In that case, the lack of difference between the $4^{\text {th }}$ and $5^{\text {th }}$ years seems to be related to the total consolidation of the conversion rules as well as the development of the lexical processes (Pinheiro, 1994; Salles \& Parente, 2002, 2006).

The regular spelling of Brazilian Portuguese enables successful reading of most words through phonological decoding. Therefore, the faster processing speeds observed in older children may reflect readers' competence in applying grapheme-phoneme correspondence rules in conjunction with the development of lexical processes (Pinheiro, Lúcio, \& Silva, 2008; Salles \& Parente, 2002, 2006).

The word subtest showed significant levels of consistency for the item-total correlation and Cronbach's alpha analyses. This confirms the homogeneity of the word subtests and the ability to discriminate words from pseudowords. This correlation shows the consistency between words in each form of the subtest. Therefore, it may be suggested that the difficulty of the items is related to the psycholinguistic characteristics of the words (regularity and frequency).

\section{Conclusion}

Our results show that the RDT word subtest has adequate psychometric properties initials and is effective at discriminating groups of children of different levels of schooling based on reading performance. Discrimination between groups was mainly due to the presence of words classified as irregular and as low frequency, but also due to reading processing speed, which decreases over the years with increasing reading competence. Analyses of internal consistency and correlations between the two subtest forms shows that the present version of the word reading subtest could be considered for studies of standardization, and may still undergo some further analysis and modifications as necessary. 
Pinheiro, E. C. M., Barbosa, T., Miranda, M. C., Baddeley, A., Navas, A. L. G. P. \& Bueno, O. F. A. (2015). Adaptation of the Word Subtest of the Reading Decision Test (RDT) for Brazilian Portuguese.

\section{References}

Alcock, K. J., Nokes, K., Ngowi, F., Musabi, C., McGregor, S., Mbise, A., \& Baddeley, A. (2000). The development of reading tests for use in a regularly spelled language. Applied Psycholinguistics, 21(4), 525-555.

Alégria, J., Leybaert, J., \& Mousty, P. (1997). Aquisição da leitura e distúrbios associados: Avaliação tratamento e teoria. In J. Grégoire \& B. Piérart (Eds.), Avaliação dos problemas de leitura: Os novos modelos teóricos e suas implicações diagnósticas (pp. 105-124). Porto Alegre, RS: Artes Médicas.

Angelini, A. L., Alves, I. C. B., Custódio, E. M., Duarte, W. F., \& Duarte, J. L. M. (1999). Matrizes Progressivas Coloridas de Raven. São Paulo, SP: Centro Editor de Testes e Pesquisas em Psicologia.

Baddeley, A., Gathercole, S., \& Spooner, A. (2003). The Reading Decision Test. London: Psychology Press.

Bayliss, D. M., Jarrold, C., Baddeley, A. D., \& Leigh, E. (2005). Differential constraints on the working memory and reading abilities of individuals with learning difficulties and typically developing children. Journal of Experimental Child Psychology, 92(1), 76-99. doi:10.1016/j.jecp.2005.04.002

Burgoyne, K., Whiteley, H. E., \& Hutchinson, J. M. (2013). The role of background knowledge in text comprehension for children learning English as an additional language. Journal of Research in Reading, 36, 132-148. doi:10.1111/j.14679817.2011.01493.x

Capovilla, F. C., Macedo, E. C., \& Charin, S. (2002). Tecnologia e modelos na avaliação de compreensão em leitura silenciosa e de reconhecimento e decodificação em leitura em voz alta. In M. T. M. Santos \& A. L. G. P. Navas (Eds.), Distúrbios de leitura e escrita: Teoria e prática (pp. 97-167). São Paulo, SP: Manole.

Coltheart, M., Curts, B., Atkins, P., \& Haller, M. (1993). Models of reading aloud: Dual-rote and parallel-distributed-processing approches. Psychological Review, 100(4), 589-608. doi:10.1037/0033-295X.100.4.589

Coltheart, M., Rastle, K., Perry, C., Langdon, R., \& Ziegler, J. (2001). DRC: A dual route cascaded model of visual word recognition and reading aloud. Psychological Review, 108(1), 204-256. doi:10.1037//0033-295X.108.1.204

Conde, F. N., \& Laros, J. A. (2007). Unidimensionalidade e a propriedade de invariância das estimativas da habilidade pela TRI. Avaliação Psicológica, 6(2), 205-215.

Cunha, V. L. O., \& Capellini, S. A. (2009). Desempenho de escolares de $1^{\mathrm{a}}$ a $4^{\mathrm{a}}$ série do ensino fundamental nas provas de habilidades metafonológicas e de leitura - PROHMELE. Revista da Sociedade Brasileira Fonoaudiologia, 14(1), 56-68.

Cunha, V. L. O., \& Capellini, S. A. (2010). Análise psicolinguística e cognitivo-linguística das provas de habilidades metalinguísticas e leitura realizadas em escolares de $2^{\mathrm{a}}$ a $5^{\mathrm{a}}$ série. Revista CEFAC, 12(5), 772-783. doi:10.1590/S151618462010005000017

Cruz, C. R. (2004). Recordação de palavras e pseudopalavras: Um estudo da relação entre memória semântica e memória episódica (Dissertação de mestrado não-publicada, Universidade Federal de São Paulo, SP, Brasil).

Ellis, A. W. (1995). Leitura, escrita e dislexia: Uma análise cognitiva. Porto Alegre, RS: Artes Médicas.

Ellis, A. W., \& Young, A. W. (1988). Human Cognitive Neuropsychology. London: Lawrence Erlbaum.

Engel de Abreu, P. M. J., Gathercole, S. E., \& Martin, R. (2011). Disentangling the relationship between working memory and language: The roles of short-term storage and cognitive control. Learning and Individual Differences, 21, 569-574. doi:10.1016/j.lindif.2011.06.002

Giusti, E., \& Befi-Lopes, D. M. (2008). Translation and crosscultural adaptation of instruments to the Brazilian Portuguese language. Pró-Fono Revista de Atualização Científica, 20(3), 207-210. doi:10.1590/S0104-56872008000300012

Godoy, D. (2008). Por que ensinar as relações grafema-fonema? Revista Psicopedagogia, 25(77), 109-119.

Jastak, J., \& Jastak, S. (1965). The Wide Range Achievement Test. Wilmington, DE: Guidance Associates.

Katz, L., Brancazio, L., Irwin, J., Katz, S., Magnuson, J., \& Whalen, D. H. (2012). What lexical decision and naming tell us about reading. Read Writ, 25(6), 1259-1282. doi:10.1007/ s11145-011-9316-9

Lupker, S. J., \& Pexman, P. M. (2010). Making things difficult in lexical decision: The impact of pseudohomophones and transposed-letter nonwords on frequency and semantic priming effects. Journal of Experimental Psychology Learning Memory and Cognition, 36(5), 1267-1289. doi:10.1037/ a0020125

Lúcio, P. S. (2008). Investigação psicométrica de uma tarefa de leitura em voz alta de palavras isoladas (Dissertação de mestrado, Universidade Federal de Minas Gerais, Belo Horizonte, MG, Brasil). Recuperada em http://www.bibliotecadigital. ufmg.br/dspace/handle/1843/VCSA-7NYTS7

Lúcio, P. S., Pinheiro, A. M. V., \& Nascimento, E. (2009). O impacto da mudança no critério de acerto na distribuição dos escores do subteste de leitura do Teste de Desempenho Escolar. Psicologia em Estudo, 14(3), 593-601. doi:10.1590/ S1413-73722009000300021

Nilsen, E., \& Bourassa, D. (2008). Word-learning performance in beginning readers. Canadian Journal of Experimental Psychology, 62(2), 110-116. doi:10.1037/1196-1961.62.2.110

Parente, M. A. M. P., Silveira, A., \& Lecours, A. R. (1997). As palavras do português. In A. R. Lecours \& M. A. M. P. Parente (Eds.), Dislexia: Implicações do sistema de escrita do português (pp. 41-55). Porto Alegre, RS: Artes Médicas.

Pinheiro, A. M. V. (1994). Leitura e escrita: Uma abordagem cognitiva. Campinas, SP: Editorial Psy.

Pinheiro, A. M. V. (1996). Contagem de frequência de ocorrência de palavras expostas a crianças na faixa de pré-escola e séries iniciais. São Paulo, SP: Associação Brasileira de Dislexia.

Pinheiro, A. M. V. (1999). Cognitive assessment of competent and impaired reading in Scottish and Brazilian children. Reading and Writing: An Interdisciplinary Journal, 11(1), 175-211. doi:10.1023/A:1007914412313

Pinheiro, A. M. V., Lúcio, P. S., \& Silva, D. M. R. (2008). Avaliação cognitiva de leitura: O efeito de regularidade grafema-fonema e fonema-grafema na leitura em voz alta de palavras isoladas no português do Brasil. Psicologia: Teoria e Prática, 10(2), 16-30.

Pinheiro, A. M. V., \& Rothe-Neves, R. (2001). Avaliação cognitiva de leitura e escrita: As tarefas de leitura em voz alta e ditado. Psicologia: Reflexão e Crítica, 14(2), 399-408. doi:10.1590/S0102-79722001000200014.

Rastle, K., \& Coltheart, M. (1999). Serial and strategic effects in reading aloud. Journal of Experimental Psychology: Human Perception and Performance, 25(2), 482-503. doi:10.1037//0096-1523.25.2.482

Salles, J. F. (2005). Habilidades e dificuldades de leitura e escrita em crianças da $2^{a}$ série: Abordagem neurospsicológica cognitiva (Tese de doutorado, Universidade Federal do Rio 
Grande do Sul, Porto Alegre, RS, Brasil). Recuperada em http://www.lume.ufrgs.br/handle/10183/4197

Salles, J. F., Jou, G. I., \& Stein, L. M. (2007). O paradigma de priming semântico na investigação do processamento de leitura de palavras. Interação em Psicologia, 11(1), 71-80.

Salles, J. F., \& Parente, M. A. M. P. (2002). Processos cognitivos na leitura de palavras em crianças: Relações com compreensão e tempo de leitura. Psicologia: Reflexão e Crítica, 15(2), 321331. doi:10.1590/S0102-79722002000200010

Salles, J. F., \& Parente, M. A. M. P. (2006). Heterogeneidade nas estratégias de leitura/escrita em crianças com dificuldades de leitura e escrita. Psico, 37(1), 83-90.

Salles, J. F., \& Parente, M. A. M. P. (2007). Avaliação da leitura e escrita de palavras em crianças de $2^{\mathrm{a}}$ série: Abordagem neuropsicológica cognitiva. Psicologia: Reflexão e Crítica, 20(2), 218-226. doi:10.1590/S0102-79722007000200007

Salles, J. F., Parente, M. A. M. P., \& Freitas, L. B. L. (2010). Leitura/escrita de crianças: Comparações entre grupos de diferentes escolas públicas. Paidéia (Ribeirão Preto), 20(47), 335-344.

Seidenberg, M. S., Waters, G. S., Barnes, M. A., \& Tanenhaus, M. K. (1984). When does irregular spelling or pronounciation influence word recognition? Journal of Verbal Learning and Verbal Behaviour, 23(3), 383-404. doi:10.1016/S00225371(84)90270-6

Stein, L. (1994). Teste de Desempenho Escolar. São Paulo, SP: Casa do Psicólogo.

Ziegler, J. C., Perry, C., \& Coltheart, M. (2003). Speed of lexical and nonlexical processing in French: The case of the regularity effect. Psychonomic Bulletin and Review, 10(4), 947-953 